\title{
NOTE
}

\section{The Leptasterias (Echinodermata: Asteroidea) species complex: variation in reproductive investment}

\author{
Sophie B. George* \\ Friday Harbor Laboratories, University of Washington, Friday Harbor, Washington 98250, USA
}

\begin{abstract}
Egg diameter, the amount of protein per egg, and the number of eggs per individual produced did not differ between 2 morphologically and genetically distinct species of seastars, Leptasterias epichlora (Brandt) and L. hexactis (Stimpson). In these 2 closely related sympatric species, variability in egg quality might be mostly attributed to environmental factors rather than genetic constraints
\end{abstract}

KEY WORDS: Egg size $\cdot$ Egg number $\cdot$ Protein content $\cdot$ Seastar

The systematics of small six-rayed seastars of the genus Leptasterias in the Puget Sound region (Washington, USA) has been controversial (Bush 1918, Fisher 1930, Chia 1966a, Kwast et al. 1990). Chia (1966a), Kwast et al. (1990), and Stickle et al. (1992) identified 3 morphologically distinct species, L. epichlora (Brandt), L. aequalis (Stimpson) and L. hexactis (Stimpson). Chia (1966a) found no differences in their reproductive cycle, embryology and brooding behaviour. He concluded that all six-rayed seastars in the Puget Sound region belong to one biological species, L. hexactis. Kwast et al. (1990) and Stickle et al. (1992) identified 2 genetically distinct forms of Leptasterias as species, $L$. hexactis and $L$. epichlora. The third form, resembling $L$. aequalis, was considered a hybrid between $L$. hexactis and $L$. epichlora. These authors stressed that these species are distinct. Most studies on the development, brooding behaviour, reproductive cycle and ecology did not distinguish among these 3 co-occurring forms of Leptasterias (Chia 1966a, b, 1968a, b, Menge 1972, 1974, 1975). This leads to the question as to whether the reproductive output varies among these 3 species and whether data on one of these species can be compared to the pooled data on all 3 species found in the literature.

\footnotetext{
- Present address: Harbor Branch Oceanographic Inst., 5600 US1 North, Fort Pierce, Florida, 34846, USA
}

Egg size, egg numbers, and the organic content of the eggs may vary within a single spawn of a single individual, among individuals from the same population, and among individuals from different populations or species (Emlet et al. 1987, McEdward \& Carson 1987. George et al. 1990, McEdward \& Chia 1991). Closely related species can have similar egg sizes or a broad range of egg sizes (Emlet et al. 1987). The present paper investigates the use of these reproductive parameters to clarify the Leptasterias species complex. $L$. epichlora and $L$. hexactis were used because they were the most abundant species in the Puget Sound region.

Materials and methods. Leptasterias epichlora and L. hexactis were collected on 27 September 1991 from Deadman Bay $\left(48^{\circ} 30^{\prime} \mathrm{N}, 123^{\circ} 09^{\prime} \mathrm{W}\right.$ ). Individuals were examined under a dissecting microscope and identified to species by ray shape, coloration, body size, and arrangement and abundance of minor and major pedicellaria (Kwast et al. 1990).

Wet body weight, egg size, numbers of eggs, and protein content of the eggs for both species were compared. Eggs were removed from the gonads by vigorously shaking and tearing the gonadal tissue in $0.45 \mu \mathrm{m}$ filtered sea water. All eggs released incidentally during dissection were collected. The total number of eggs produced by a female was counted using a dissecting microscope. The diameters of 40 to 80 eggs per female were measured using a compound microscope equipped with an ocular micrometer. For protein analysis, samples of 10 eggs per female were held at $-80^{\circ} \mathrm{C}$. Five such samples were prepared for each female. The concentration of protein was measured by the method of Lowry et al. (1951).

Statistical tests were carried out with SAS ${ }^{\text {(B) }}$ software (SAS Institute, Inc. 1988) and SYSTAT (Wilkinson 1989), using methods described by Sokal \& Rohlf (1981) 
and Neter et al. (1990). Nested ANOVAs (balanced designs) with species as a fixed factor and females as a random factor were carried out to show variation in egg diameter and protein content among females and between species on untransformed data. In order to have the same number of levels for the nested factor (females), some females were randomly eliminated from the nested ANOVA analyses. Analysis of covariance (ANCOVA) tested the relationship between body wet weight (the independent variable) and the number of eggs produced. The number of eggs produced per female was square-root-transformed to correct heteroscedasticity.

Results. Nested analysis of variance on balanced data showed no significant differences in egg diameter and protein content per egg between the 2 species (Table 1). The mean egg diameter was $976.9 \pm$ $110.9 \mu \mathrm{m}$ ( $\mathrm{n}$, the total number of eggs measured $=576$ ) and the mean protein content per egg was $40.5 \pm 4.9 \mu \mathrm{g}$ $\mathrm{egg}^{-1}$ ( $\mathrm{n}$, the total number of samples $=42$ ) for Leptasterias epichlora and $971.9 \pm 125.0(\mathrm{n}=448)$ and $40.1 \pm 8.6$ ( $n=41$ ) for $L$. hexactis. The major part of the variation in egg size ( $42.6 \%$ of the total variation) and protein content per egg $(45.0 \%$ of the total variation) was due to significant variation among females. The rest of the variation was among eggs produced by a single female and thus protein content per egg (Table 1).

For both species, the separate regressions of the number of eggs per female on wet body weight were linear $(F=38.8, \mathrm{p}<0.0001)$ and did not differ in slope $(F=2.0$; Table 2, Fig. 1). No significant differences were observed in the number of eggs per female between the 2 species when wet body weight was kept constant ( $F=2.4, \mathrm{p}=0.1$; Table 2 ). The mean number of eggs produced was $541 \pm 170(\mathrm{n}=9)$ for Leptasterias epichlora and was $409 \pm 275(n=11)$ for $L$. hexactis.

Discussion. The present study suggests that comparing data on one of these species with pooled data on all 3 species of Leptasterias as in Chia (1966a, 1968a) and Menge (1972, $1974,1975)$ is valid. Despite morphological and genetic differences between these co-occurring species (Kwast et al. 1990, Stickle et al. 1992,
Foltz \& Stickle in press, Stickle \& Foltz in press) egg sizes, egg numbers, and protein content per egg are similar. This might be because of the extensive hybridisation between these 2 co-occurring species (Kwast et al. 1990),

The present results are consistent with those of Emlet et al. (1987) in that significant variation in egg size, egg number, and the amount of protein in the egg was observed among females. In agreement with Chia (1966a) a strong correlation between the number of eggs produced and female body weight was observed. Large females of the seastar Leptasterias epichlora produce more large, higher quality eggs than small females (George 1994). The large seastar $L$. polaris ( 70 to $200 \mathrm{~g}$ wet $w \mathrm{t}$ ) produces over 3000 eggs (Himmelman et al. 1982). Thus the major part of the variation

Table 1. Leptasterias epichlora, L. hexactis. Nested analyses of variance of egg diameter $(\mu \mathrm{m})$ and protein content $\left(\mu \mathrm{g} \mathrm{egg}^{-1}\right)$

\begin{tabular}{|c|c|c|c|c|c|c|}
\hline $\begin{array}{l}\text { Source of } \\
\text { variation }\end{array}$ & SS & $\mathrm{df}$ & MS & $F$ & va & $\begin{array}{l}\text { Percentage of } \\
\text { variance component }\end{array}$ \\
\hline \multicolumn{7}{|c|}{ Egg diameter } \\
\hline Species & 82174.1 & 1 & 82174.1 & 0.5 & 0.5 & \\
\hline Females & 3224310.3 & 18 & 179128.4 & 24.8 & $<0.0001$ & 42.6 \\
\hline Error & 4479752.1 & 620 & 7225.4 & & & 57.4 \\
\hline Total & 7786236.5 & 639 & 12185.0 & & & \\
\hline \multicolumn{7}{|c|}{ Protein content per egg } \\
\hline Species & 13.8 & 1 & 13.8 & 0.1 & 0.7 & \\
\hline Females & 1890.0 & 16 & 118.1 & 4.3 & $<0.0001$ & 44.9 \\
\hline Error & 1495.4 & 54 & 27.7 & & & 55.1 \\
\hline Total & 3399.2 & 71 & 47.9 & & & \\
\hline
\end{tabular}

Table 2. Analyses of covariance of the number of eggs per female (square-roottransformed) for Leptasterias epichlora and $L$. hexactis. Wet body weight is the covariate

\begin{tabular}{|c|c|c|c|c|}
\hline Test & Source of variation & SS & MS & $F$ \\
\hline \multirow[t]{2}{*}{$\begin{array}{l}\text { Test for linearity } \\
\text { within species }\end{array}$} & $\begin{array}{l}\text { Common slope } \\
\text { within species }\end{array}$ & 404.453 & 404.453 & \multirow[t]{2}{*}{$38.8 \cdots$} \\
\hline & $\begin{array}{l}\text { Deviations from } \\
\text { a common slope }\end{array}$ & 177.203 & 10.424 & \\
\hline \multirow{3}{*}{$\begin{array}{l}\text { Test for homogeneity } \\
\text { of slopes of regression } \\
\text { coefficients }\end{array}$} & $\begin{array}{l}\text { Differences between } \\
\text { separate slopes }\end{array}$ & 19.887 & 19.887 & \multirow[t]{3}{*}{$2.0 \mathrm{~ns}$} \\
\hline & $\begin{array}{l}\text { Deviations in each species } \\
\text { from its separate slope }\end{array}$ & 157.238 & 9.827 & \\
\hline & Total & 655.233 & & \\
\hline \multirow[t]{2}{*}{ Final ANCOVA } & $\begin{array}{l}\text { Adjusted means } \\
\text { between species }\end{array}$ & 24.636 & 24.636 & \multirow[t]{2}{*}{$2.4 \mathrm{~ns}$} \\
\hline & $\begin{array}{l}\text { Deviations from } \\
\text { a common slope }\end{array}$ & 177.203 & 10.424 & \\
\hline
\end{tabular}




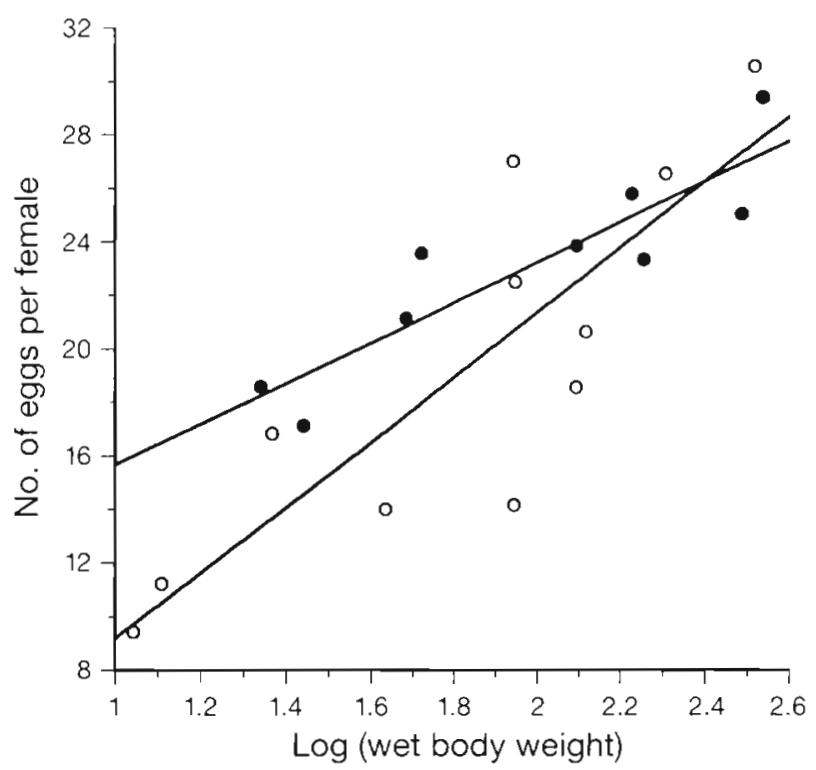

Fig. 1. Leptasterias epichlora, L. hexactis. Number of eggs per female (square-root-transformed) versus wet body weight ( $g$ ) for the seastars Leptasterias epichlora (•) and Leptasterias hexactis (0)

observed in the reproductive parameters measured among females might be due to differences in female body size. Variation in egg number and quality might result from both genetic and environmental factors. As Stickle (1985) pointed out, production of somatic tissue and gametes by the seastar L. hexactis is strongly influenced by environmental factors. The degree of influence from environmental sources depends largely on conditions experienced by a female during the time energy is being acquired and converted towards oogenesis. Female $L$. epichlora from a favourable site produce large, higher quality eggs than females from a less favorable site (George 1994).

Acknowledgements. I thank all those at Friday Harbor Laboratories who helped in various ways to make this study successful. I especially thank R. Strathmann, G. Gibson, G. Brown, J. Murray, D. McHugh, S. Renn, J. Zardus, and others for collecting samples in the field, and R. Strathmann, $M$. Strathmann, J. Lawrence, and C. Young who read earlier versions of the manuscript. This study was supported by a Postdoctorate Fellowship from Friday Harbor Laboratories, University of Washington.

\section{LITERATURE CITED}

Bush, M. (1918). Key to the echinoderms of Friday Harbor, Washington. Publ. Puget Sound Biol. Sta. 2: 17-44

Chia, F. S. (1966a). Systematics of the six-rayed sea star, Leptasterias, in the vicinity of San Juan Island, Washington. Syst. Zool. 15: 300-306

Chia, F. S. (1966b). Brooding behavior of a six-rayed starfish, Leptasterias hexactis. Biol. Bull. 130: 304-315
Chia, F. S. (1968a). Some observations on the development and cyclic changes of the oocytes in the brooding starfish. Leptasterias hexactis. J. Zool. Lond. 154: 453-461

Chia, F. S. (1968b). The embryology of a brooding starfish, Leptasterıas hexactis (Stimpson). Acta Zool. 49: 1-44

Emlet, R. B., McEdward, L. R., Strathmann, R. R. (1987). Echinoderm larval ecology viewed from the egg. Echinoderm Stud. 2: 55-136

Fisher, W. K. (1930). Asteroidea of the North Pacific and adjacent waters. Part 3. Forcipulata. Bull. U.S. natn. Mus 76: $1-255$

Foltz, D. W., Stickle, W. B. (in press). Genetic structure of four species in the Leptasterias hexactis complex along the Pacific coast of North America. In: David, B. (ed.) Proc. of the 8 th int. Echinoderm Conf., Dijon, France, September 6-10, 1993. A. A. Balkema, Rotterdam

George, S. B. (1994). Population differences in maternal size and offspring quality for Leptasterias epichlora (Brandt) (Echinodermata: Echinoidea). J. exp. mar. Biol. Ecol. 175 $121-131$

George, S. B., Cellario, C., Fenaux, L. (1990). Population differences in egg quality of Arbacia lixula (Echinodermata: Echinoidea): proximate composition of eggs and larval development. J. exp. Mar. Biol. Ecol. 141: $107-118$

Himmelman, J. H., Lavergne, Y., Cardinal, A., Martel, G., Jalbert, P. (1982). Brooding behaviour of the northern seastar Leptasterias polaris. Mar. Biol. 68: 235-240

Kwast, K. E., Foltz, D. W., Stickle, W. B. (1990). Population genetics and systematics of the Leptasterias hexactis (Echinodermata: Asteroidea) species complex. Mar Biol. 105: $477-489$

Lowry, O. H., Rosenborough, N. J., Farr, A. L., Randall, R. J (1951). Protein measurement with the Folin phenol reagent. J. Biol. Chem. 193: 265-275

McEdward, L. R., Carson, F. (1987). Variation in egg organic content and its relationship with egg size in the star fish Solaster stimpsoni. Mar. Ecol. Prog. Ser 37 : $159-169$

McEdward, L. R., Chia, F. S. (1991). Size and energy content of eggs from echinoderms with pelagic lecithotrophic development. J. exp. mar. Biol. Ecol. 147: 95-102

Menge, B. A. (1972). Competition for food between two intertidal starfish species and its effect on body size and feeding. Ecology 53: 635-644

Menge, B. A. (1974). Effect of wave action and competition on brooding and reproductive effort in the seastar, Leptasterias hexactis. Ecology 55: $84-93$

Menge, B. A. (1975). Brood or broadcast? The adaptive significance of different reproductive strategies in two intertidal seastars Leptasterias hexactis and Pisaster ochraceus. Mar. Biol 31: 87-100

Neter, J., Wasserman, W., Kutner, M. (1990). Applied linear statistical models, 2nd edn. Richard E. Irwin, Inc., Homewood, IL

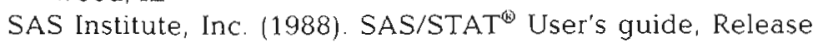
6.03 edn. SAS Institute, Inc. Cary, NC

Sokal, R. R., Rohlf, F. J. (1981). Biometry, 2nd edn. W. H. Freeman and Co. San Francisco

Stickle, W. B. (1985). Effects of environmental factor gradients on scope for growth in several species of carnivorous marine invertebrates. In: Gray, J. S., Christiansen, M. E. (eds.) Marine biology of polar regions and effects of stress on marine organisms. Wiley, New York, p. 601-615

Stickle, W. B., Foltz, D. W. (in press). Distribution of species in the Leptasterias hexactis (Stimpson) species complex along the Pacific coast of North America. In: David, B. (ed). 
Proc. of the 8th int. Echinoderm Conf., Dijon, France, September $6-10,1993$. A. A. Balkema, Rotterdam

Stickle, W. B., Foltz, D. W., Katoh, M., Nguyen, H. L. (1992).

Genetic structure and mode of reproduction in five species

This note was submitted to the editor of sea stars (Echinodermata: Asteroidea) from the Alaskan coast. Can. J. Zool. 70: 1723-1728

Wilkinson, L. (1989). SYSTAT: the system for statistics. SYSTAT, Inc., Evanston, IL

Manuscript first received: October 12, 1993

Revised version accepted: March 24, 1994 